\title{
Manfaat Kanopi Pohon dalam Mereduksi Aliran Permukaan Studi Kasus: Sempadan Sungai Ciliwung Tengah, Kota Bogor
}

\author{
FLORENTHIUS AGUNG NUGROHO ${ }^{1}$, INDUNG SITTI FATIMAH ${ }^{2 *}$ \\ ${ }^{1}$ Arsitektur Lanskap, Fakultas Pertanian, Institut Pertanian Bogor \\ Jalan Raya Darmaga Kampus IPB, Dramaga, Bogor, Jawa Barat 16680 \\ 2 Divisi Perencanaan dan Desain Arsitektur Lanskap, Institut Pertanian Bogor \\ Jalan Raya Darmaga Kampus IPB, Dramaga, Bogor, Jawa Barat 16680
}

*E-mail: indungsittifatimah@gmail.com

\section{ABSTRACT \\ The Benefit of Trees Canopy in Reducing Runoff Case Study: Border of Center Ciliwung River, Bogor Municipality}

Bogor as one of Center Ciliwung Sub Region River flow has decreased the percentage of green open space from year to year (Bappeda 2007). Study area boundary is the border as far as 300 meters to the left and right side of Ciliwung River. The method of this research is to estimating the benefits of tree canopy using Quickbird satellite image of the city of Bogor in 2006 with the software ArcView GIS 3.2 extensions CITYgreen 5.4. The study includes comparisons between the percentage of built up area and green open space. Comparison of built up area and the largest area of green open space can be found in Tanah Sareal District, the ratio reached 2:1. While the smallest ratio can be found in the Middle District of Bogor (1:1). This means the ideal condition of river's border are found in the Middle District of Bogor that can decreasing runoff well. The estimation of trees canopy benefits can be seen from the amount of runoff volume, it can be predicted that trees canopy in study area can reduce average $\pm 7,55 \%$ of runoff volume. This means that the conditions in the study area was still below the average standard riverine.

Keywords: Ciliwung river, CITYgreen 5.4, stormwater runoff, green open space treescanopy

\section{Pendahuluan}

Bogor adalah salah satu kota besar di provinsi Jawa Barat yang telah mengalami perkembangan sangat signifikan. Arah negatif dari perkembangan kota salah satunya adalah menurunnya persentase ruang terbuka hijau (RTH) kota. Akibatnya kualitas lingkungan kota menurun dan laju aliran permukaan semakin meningkat (Bappeda 2007).

Sungai Ciliwung merupakan salah satu sungai yang melintasi Kota Bogor, Kabupaten Bogor, Depok dan Jakarta. Dari 13 sungai yang mengalir di Jakarta, Sungai Ciliwung memberikan dampak yang paling luas bagi Kota Jakarta ketika musim hujan, karena banjir yang ditimbulkan dari sungai ini. Masalah yang sampai sekarang belum dapat diatasi dengan baik oleh pemerintah ini salah satu penyebab utamanya adalah meningkatnya laju 
aliran permukaan akibat perubahan tata guna lahan di sepanjang Sungai Ciliwung dan daerah di sekitarnya (Daerah Aliran Sungai).

Kota Bogor termasuk wilayah DAS Ciliwung bagian tengah dan merupakan salah satu daerah yang mengalami perubahan tata guna lahan cukup signifikan. Menurut data Bappeda mengenai tata guna lahan dalam Laporan Akhir Master Plan Drainase Kota Bogor tahun 2007, pada tahun 2009 permukiman mendominasi peningkatan penggunaan lahan mencapai $36 \%$ dari tata guna lahan permukiman tahun 2005. Kondisi tersebut mengakibatkan RTH di Kota Bogor menjadi semakin berkurang, sehingga daerah resapan air hujan juga akan semakin berkurang. Nurisjah dan Pramukanto (1995) menyatakan bahwa RTH merupakan bagian dari suatu ruang terbuka (open space) kota yang secara optimal digunakan sebagai daerah penghijauan dan berfungsi secara langsung maupun tidak langsung untuk kehidupan dan kesejahteraan warga kotanya.

Dalam Laporan Akhir Master Plan Drainase Kota Bogor tahun 2007, akibat pembangunan infrastruktur kota maka banyak lahan resapan air berubah menjadi lahan kedap air, sehingga mengakibatkan aliran permukaan tidak dapat meresap ke dalam tanah. Hal ini akan menyebabkan debit sungai meningkat dan berkurangnya air tanah. Untuk itu diperlukan penelitian tentang pengaruh penutupan lahan terhadap laju aliran permukaan yang semakin lama semakin bertambah di Kota Bogor. Adapun tujuan dari penelitian ini antara lain, 1) menghitung rasio perbandingan luas areal terbangun dengan luas RTH di sepanjang sempadan Sungai Ciliwung yang melalui Kota Bogor di empat kecamatan (Kecamatan Bogor Timur, Kecamatan Bogor Tengah, Kecamatan Bogor Utara dan Kecamatan Tanah Sareal), dan 2) pendugaan manfaat kanopi pohon dalam mereduksi aliran permukaan dengan CITYgreen dan membandingkan hasilnya.

\section{Metode}

\subsection{Lokasi Penelitian}

Penelitian ini dilakukan di sepanjang Sungai Ciliwung bagian tengah Kota Bogor dengan batasan berupa sempadan sungai sejauh 300 meter sebelah kiri dan kanan sungai (Gambar 1), berdasarkan aturan pemerintah dalam PP No.47/1997 yang menentukan lebar sempadan sungai sejauh 50-100 meter, namun dalam penelitian ini ditentukan sejauh 300 meter dengan tujuan agar hasil penelitian dapat lebih beragam dan valid.

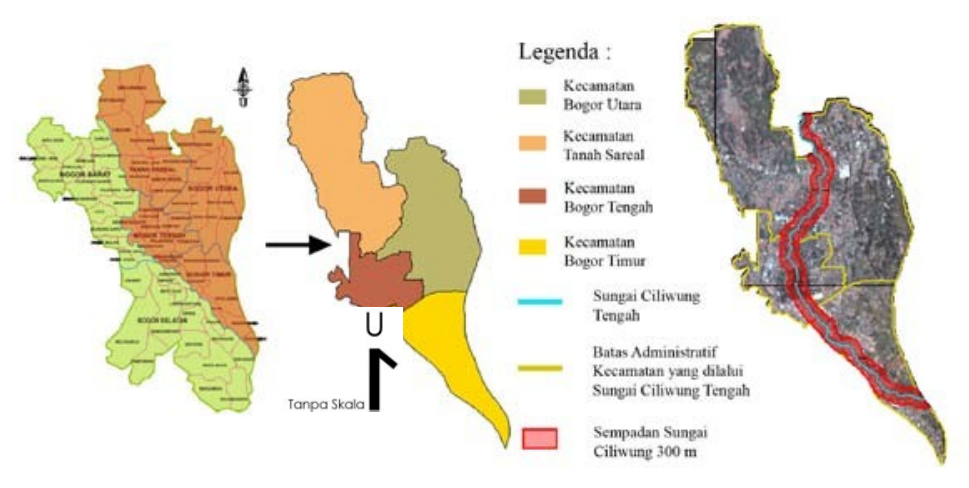

\subsection{Alat dan Bahan}

Gambar 1. Peta lokasi penelitian

Alat dan bahan yang digunakan terdiri dari :

1. Citra Satelit Quick Bird Kota Bogor Tahun 2006.

2. Software ArcView 3.2. 
3. Extention CITYgreen 5.4, Xtool, Image Analyst, Spatial Analyst.

\subsection{Metode Penelitian}

Penelitian ini dilakukan dengan metode deskriptif dengan pengkajian melalui data sekunder serta pengolahan data dengan GIS (Tabel 1).

Tabel 1. Jenis, Sumber dan Fungsi Data

\begin{tabular}{llll}
\hline No & \multicolumn{1}{c}{ Jenis Data } & \multicolumn{1}{c}{ Sumber Data } & \multicolumn{1}{c}{ Fungsi Data } \\
\hline 1 & Citra Satelit Quick Bird & Lab. Tanaman dan Tata Hijau Departemen & Data spasial \\
& (2006) & Arsitektur Lanskap, IPB & Data Atribut \\
Data Iklim (2007-2008): & & \\
& $\begin{array}{l}\text { 1. Curah Hujan } \\
\text { 2. Kelembaban }\end{array}$ & \\
& $\begin{array}{l}\text { 3. Kecepatan Angin } \\
\text { 4. Suhu Udara }\end{array}$ & & \\
& 5. Penyinaran Matahari & Bappeda Kota Bogor (Master Plan Drainase & \\
& 6. Kualitas Udara & Kota Bogor 2007) & Data Atribut \\
3 & Data Geologi (2005): & & \\
& 1. Jenis Tanah & & Data Atribut \\
4 & 2. Tata Guna Lahan & & Data Atribut \\
Data Hidrologi (1983-2007) & Topografi dan Klasifikasi & & \\
\hline
\end{tabular}

\subsection{Analisis dengan CITYgreen 5.4 Ekstensi ArcView 3.2}

ArcView adalah salah satu software yang digunakan untuk menganalisis sebuah peta sehingga menghasilkan data berbentuk spasial. Perangkat lunak ini terdiri dari beberapa versi, untuk penelitian ini digunakan ArcView versi 3.2. Khusus untuk kebutuhan RTH diperlukan ekstensi (program tambahan) CITYgreen 5.4 yang dapat menganalisis beberapa aspek, yaitu aliran permukaan (Stormwater Run Off), kualitas udara (Air Quality), penyimpanan karbon dan daya serap karbon (Carbon Storage and Sequestration), konservasi energi (Energy Savings), dan permodelan perkembangan RTH.

Konsep dasar CITYgreen 5.4 adalah mengidentifikasi lahan berupa canopy dan non canopy. Data canopy adalah digitasi citra satelit yang menampilkan tampak atas pohonpohon yang memiliki diameter tajuk lebih dari 4 meter. Data noncanopy terdiri dari badan air, bangunan dan lahan terbuka (area persawahan, lapangan rumput, perkerasan, plaza, dan lain-lain). Salah satu aspek yang dapat dianalisis dengan CITYgreen 5.4 adalah menghitung besarnya laju aliran permukaan (runoff) untuk mengantisipasi banjir. Pada penelitian ini difokuskan hanya menganalisis aspek runoff saja, sedangkan empat aspek lainnya akan dilakukan untuk studi lebih lanjut.

Kanopi pohon menjadi salah satu variabel dalam tahap analisis software CITYgreen 5.4 dan pada kondisi sesungguhnya kanopi pohon dapat menjadi komponen dalam sistem manajemen banjir (Budiman 2010). CITYgreen 5.4 menilai bagaimana penutupan lahan, tipe tanah, kemiringan, dan penyerapan mempengaruhi volume aliran permukaan, waktu konsentrasi aliran dan aliran puncak (American Forest 2002). Hasil analisis berupa perhitungan aliran air yang harus disimpan oleh kanal penahan banjir, jika diandaikan vegetasi/kanopi pohon pada area yang diteliti dihilangkan. Selanjutnya, hasil volume air dapat dikalikan dengan biaya konstruksi pembangunan kanal, sehingga akan dapat dihitung biaya yang dihemat dengan kanopi pohon yang tumbuh di tempat tersebut. 
Berikut beberapa aspek yang dapat dianalsis dengan CITYgreen 5.4 dan data yang diperlukan.

Tabel 2. Data yang Dibutuhkan dalam Analisis

\begin{tabular}{lll}
\hline \multicolumn{1}{c}{ Required } & \multicolumn{1}{c}{$\begin{array}{c}\text { Values Acquired from } \\
\text { data Within CITYgreen } \\
\text { And User Definable }\end{array}$} \\
\hline Stormwater & Land cover, tree canopy & $\begin{array}{l}\text { Slope, hydrologic soil } \\
\text { group, 2-year/24-hour rainfall info, } \\
\text { rainfall distribution type } \\
\text { Closest air quality city }\end{array}$ \\
Air Quality & Tree canopy & $\begin{array}{l}\text { Roof albedo, heating system, roof } \\
\text { insulation R-value,locations of windows } \\
\text { and air conditioners } \\
\text { Tree health class, } \\
\text { growing condition }\end{array}$ \\
\hline Modeling & $\begin{array}{l}\text { Tree canopy, building height, } \\
\text { species, tree height class, }\end{array}$ &
\end{tabular}

Sumber: CITYgreen Manual User 2002

\section{Pembahasan}

\subsection{Hasil Analisis GIS dengan CITYgreen 5.4}

Proses analisis dibagi atas empat kecamatan yang berbeda, dimulai dari kecamatan yang berada di bagian selatan sempadan sungai, yaitu Kecamatan Bogor Timur. Setiap Kecamatan terbagi lagi menurut perbedaan kemiringan lereng, hal ini bertujuan agar hasil analisis dapat dibandingkan di setiap kemiringan lereng dan mengetahui sejauh mana perbedaan nilai yang ditunjukkan. Sesuai dengan tujuan penelitian, hasil dan pembahasan terbagi menjadi dua bagian. Bagian pertama adalah perhitungan rasio antara area terbangun dan RTH. Area terbangun dalam studi ini mencakup lahan kedap air dan lahan perkotaan, sedangkan RTH mencakup kanopi pohon. Berikut adalah hasil perbandingan persentase antara area terbangun dengan RTH (Gambar 2).

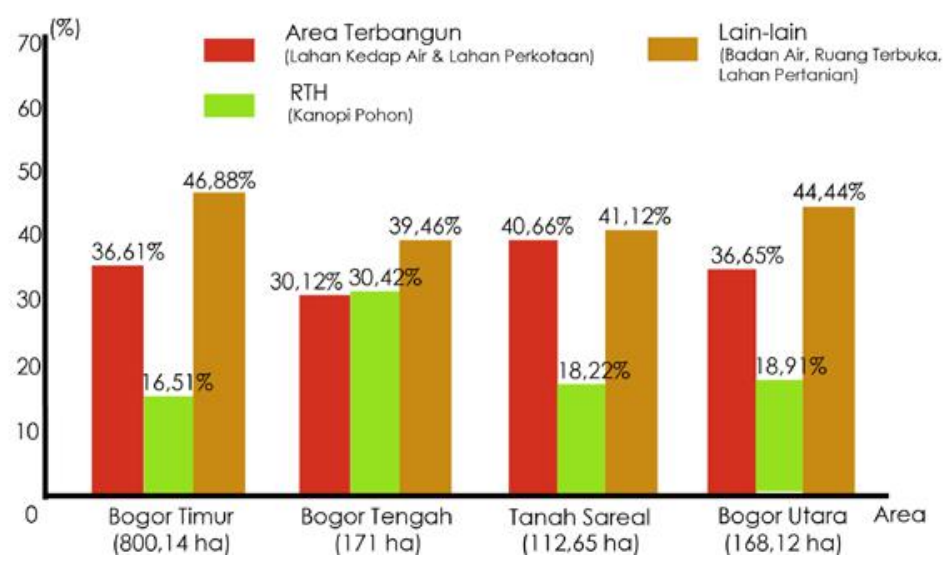

Gambar 2. Hasil perbandingan area terbangun dan RTH

Perbandingan area terbangun dengan RTH didapat bahwa yang memiliki nilai rasio terbesar adalah Kecamatan Tanah Sareal dengan persentase area terbangun sebesar $40,66 \%$ dan RTH sebesar 18,22\% serta tutupan lain-lain sebesar $41,12 \%$ dari luas total (Gambar 2), atau secara sederhana rasio yang diperoleh adalah $2: 1$ (terbangun : RTH), 
sedangkan yang memiliki rasio terkecil adalah Kecamatan Bogor Tengah dengan persentase area terbangun sebesar 30,12\% dan RTH sebesar 30,42 \% serta tutupan lain sebesar 39,46\% dari luas total (Gambar 2), atau secara sederhana rasio yang diperoleh adalah 1 : 1 (terbangun : RTH). Berdasarkan Kepres No. 32/1990 dan PP No. 47/1997, kondisi sempadan pada Kecamatan Bogor Tengah dikatakan ideal dengan proporsi terbangun, RTH, dan lain-lain seimbang, sedangkan tiga Kecamatan lain dikategorikan kurang ideal. Jika ditinjau dari kondisi lapang di Kecamatan Tanah Sareal, tutupan lahan didominasi oleh rumah-rumah penduduk, mulai dari komplek perumahan hingga perkampungan di bantaran sungai, sehingga tutupan kanopi pohon sedikit ditemui di daerah ini, terlebih pembangunan Jalan Kyai Haji Soleh Iskandar yang memangkas cukup banyak pohon eksisting di sepanjang jalurnya.

Kecamatan Bogor Tengah memiliki persentase RTH yang terbesar dari tiga kecamatan lain, yaitu sejumlah 30,42\% dari luas total Kecamatan Bogor Tengah (Gambar 2). Hal ini sungguh relevan jika dikaitkan dengan kondisi sesungguhnya daerah ini, dimana terdapat area hutan kota (Kebun Raya Bogor), yang sebagian besar lahan tertutupi oleh tajuk pohon.

Bagian kedua hasil penelitian adalah pendugaan manfaat kanopi pohon dalam mereduksi aliran permukaan. Pendugaan manfaat kanopi pohon ditinjau dari besarnya volume aliran permukaan yang didapat dari analisis menggunakan CITYgreen 5.4. Berikut merupakan hasil volume aliran permukaan pada masing-masing area studi.

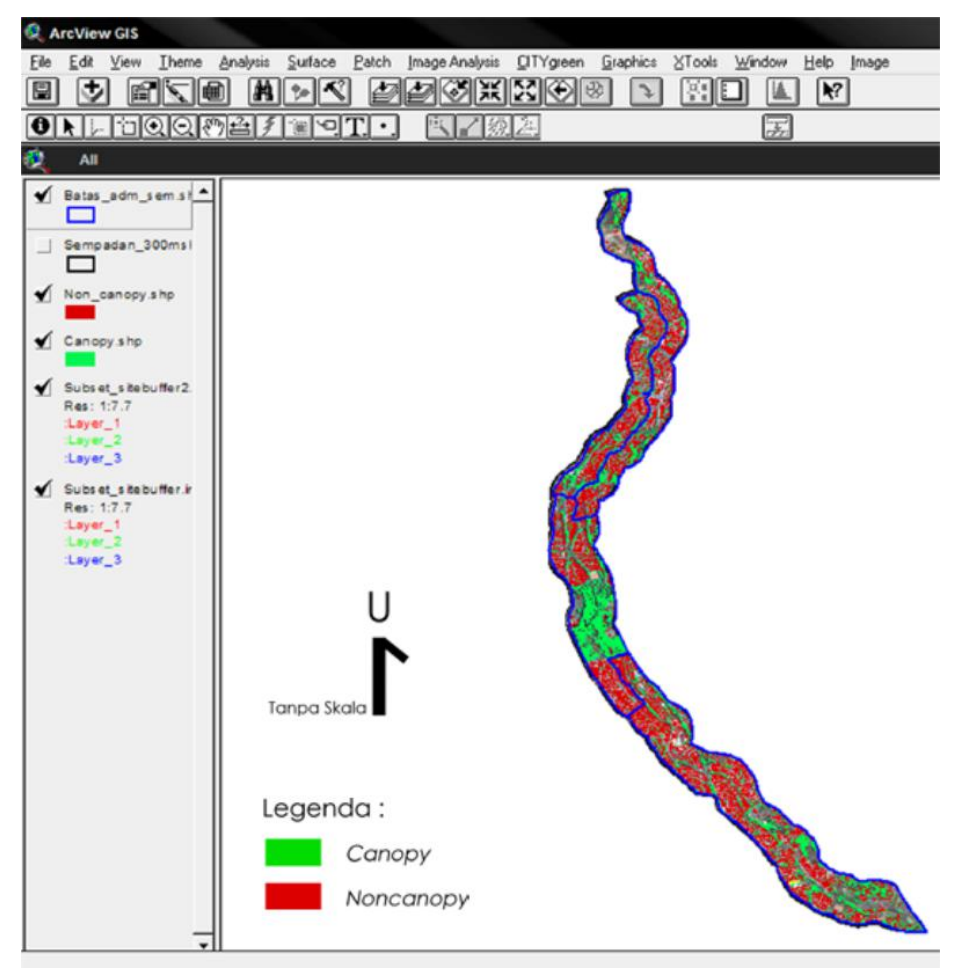

Gambar 3. Hasil akhir digitasi theme canopy (RTH) dan noncanopy (terbangun) di Empat Kecamatan 


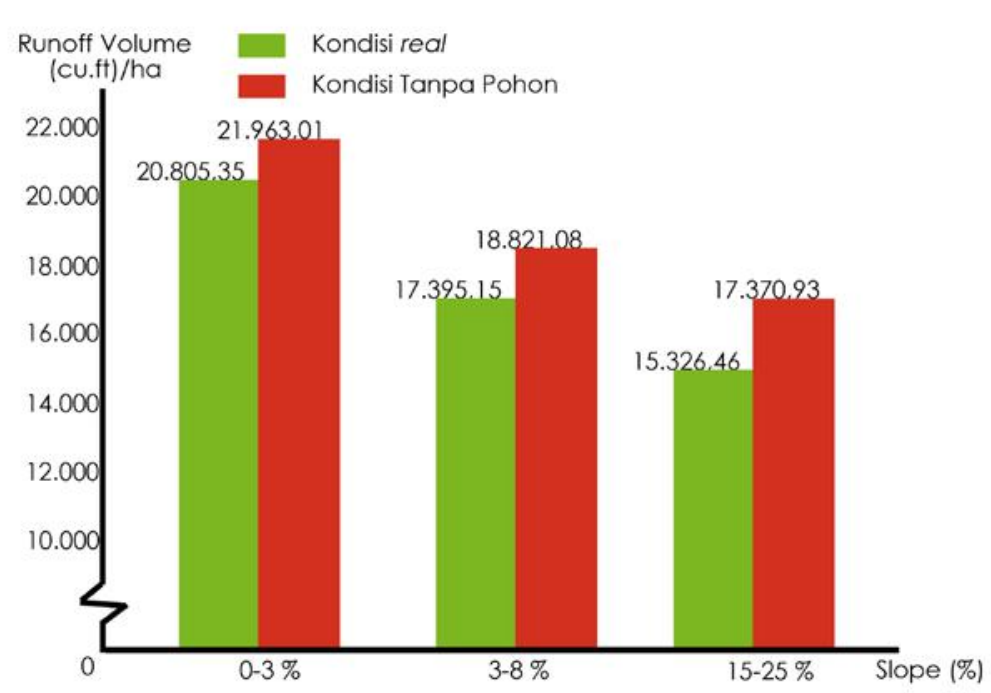

Gambar 4. Diagram perbandingan volume aliran permukaan Kecamatan Bogor Timur

Dari diagram hasil di atas, dapat terlihat bahwa volume aliran permukaan terbesar terdapat di Kecamatan Bogor Tengah pada kemiringan 15-25\% dengan jumlah 22.780,27 $\mathrm{ft}^{3} / \mathrm{ha}$ atau setara dengan $645.06 \mathrm{~m}^{3} / \mathrm{ha}\left(1 \mathrm{ft}^{3}=0,0283 \mathrm{~m}^{3}\right)$ pada kondisi real dan berjumlah $23.637,43 \mathrm{ft} / \mathrm{ha}$ atau setara dengan $669.34 \mathrm{~m}^{3} / \mathrm{ha}$ pada kondisi tanpa kanopi pohon. Sedangkan area yang memiliki volume aliran permukaan terkecil adalah Kecamatan Bogor Tengah pada kemiringan lereng 3-8\% dengan jumlah 10.054,13 ft3/ha atau setara dengan $284.70 \mathrm{~m}^{3} / \mathrm{ha}$ pada kondisi real dan berjumlah $11.676,61 \mathrm{ft} / \mathrm{ha}$ atau setara dengan $330.64 \mathrm{~m}^{3} / \mathrm{ha}$ pada kondisi tanpa kanopi pohon. Berikut hasil report CITYgreen 5.4 pada kedua area.

\subsection{Kecamatan Bogor Tengah (Kemiringan Lereng 8-15\%)}

A. Statistik Tapak

1. Area Analisis : Kota Bogor Tengah

2. Skenario : Kondisi Tertentu

3. Area : 0,02 sq miles $=9,98$ acre $=4,04$ hectares

Distribusi Penutupan Lahan:
1. Lahan Kedap Air
$: 60,89 \%(6,08$ acres $)$
2. Lahan Perkotaan
: $0,03 \%(0,0003$ acres $)$
3. Badan Air
$: 7,10 \%(0,71$ acres $)$
4. Kanopi Pohon
: 6,76\% (0,67 acres)
5. Ruang Terbuka
: 25,22\% (2,25 acres)

B. Manfaat Ekologi

Kontrol Aliran Permukaan :

1. Rata-rata 2 tahun, curah hujan per 24 jam (inch): 3,5

2. Rata-rata kemiringan tapak (\%) :0,12

3. Pengelompokkan wilayah distribusi hujan : III

4. Jenis Hidrologi Tanah : $\mathrm{B}$ 
5. Volume penyimpanan yang dibutuhkan untuk mengurangi perubahan aliran puncak (cu.ft) 11.230,04

6. Biaya Konstruksi (@ \$2,00/ cu ft) \$22.460,07

$\begin{array}{llll} & & \text { Kondisi Sekarang } & \text { Model Tanpa Pohon } \\ 1 & \text { Angka Kurva } & 91 & 92 \\ 2 & \text { Kedalaman Aliran (m) } & 2,54 & 2,64 \\ 3 & \text { Waktu konsentrasi (hrs) } & 0,89 & 0,85 \\ 4 & \text { Panjang Aliran (cfs) } & 12,5 & 13,26 \\ 5 & \text { Volume Aliran (cu.ft) } & 92.032,32 & 95,495,21\end{array}$

\subsection{Kecamatan Bogor Tengah (Kemiringan Lereng 3-8\%)}

A. Statistik Tapak

1. Area Analisis : Kota Bogor Tengah

2. Skenario : Kondisi Tertentu

3. Area : 0,38 sq miles $=242,88$ acre $=98,29$ hectares

Distribusi Penutupan Lahan:
1. Lahan Kedap Air
: $15,39 \%$ (37,36 acres)
2. Lahan Perkotaan
: 1,99\% (4,83 acres)
3. Badan Air
: 4,20\% (10,20 acres)
4. Kanopi Pohon
: 43,72\% (106,20 acres)
5. Ruang Terbuka
: $34,70 \%$ (84,28 acres)

B. Manfaat Ekologi

Kontrol Aliran Permukaan :

1. Rata-rata 2 tahun, curah hujan per 24 jam (inch): 3,5

2. Rata-rata kemiringan tapak (\%) :0,06

3. Pengelompokkan wilayah distribusi hujan : III

4. Jenis Hidrologi Tanah : B

5. Volume penyimpanan yang dibutuhkan untuk mengurangi perubahan aliran puncak (cu.ft) 204.154,71

6. Biaya Konstruksi (@ \$2,00/ cu ft) $\$ 408.309,42$

$\begin{array}{llll} & & \text { Kondisi Sekarang } & \text { Model } \\ 2 & \text { Angka Kurva } & 72 & 75 \\ 3 & \text { Kedalaman Aliran (m) } & 1,12 & 1,30 \\ 3 & \text { Waktu konsentrasi (hrs) } & 10,92 & 10,04 \\ 4 & \text { Panjang Aliran (cfs) } & 23,00 & 28,95 \\ 5 & \text { Volume Aliran (cu.ft) } & 988.220,65 & 7\end{array}$

Jika ditinjau dari kondisi lapang, area Kecamatan Bogor Tengah pada kemiringan lereng 8-15\% memiliki sedikit tutupan kanopi pohon dan didominasi oleh area terbangun seperti rumah penduduk, jalan aspal, ruko, perkerasan, dan sebagainya. Area terbangun memiliki persentase $60,89 \%$ dan tutupan kanopi pohon hanya 6,76\% (Gambar 7) dari luas total area 4,04 ha. Hal sebaliknya terjadi pada area Kecamatan Bogor Tengah pada 
kemiringan lereng 3-8\%, dimana terdapat lahan yang didominasi oleh hutan kota yaitu Kebun Raya Bogor, yang memiliki tutupan kanopi pohon mencapai $43,72 \%$ dan lahan kedap air hanya sebesar 15,39\% (Gambar 8) dari luas total area 98,29 ha.

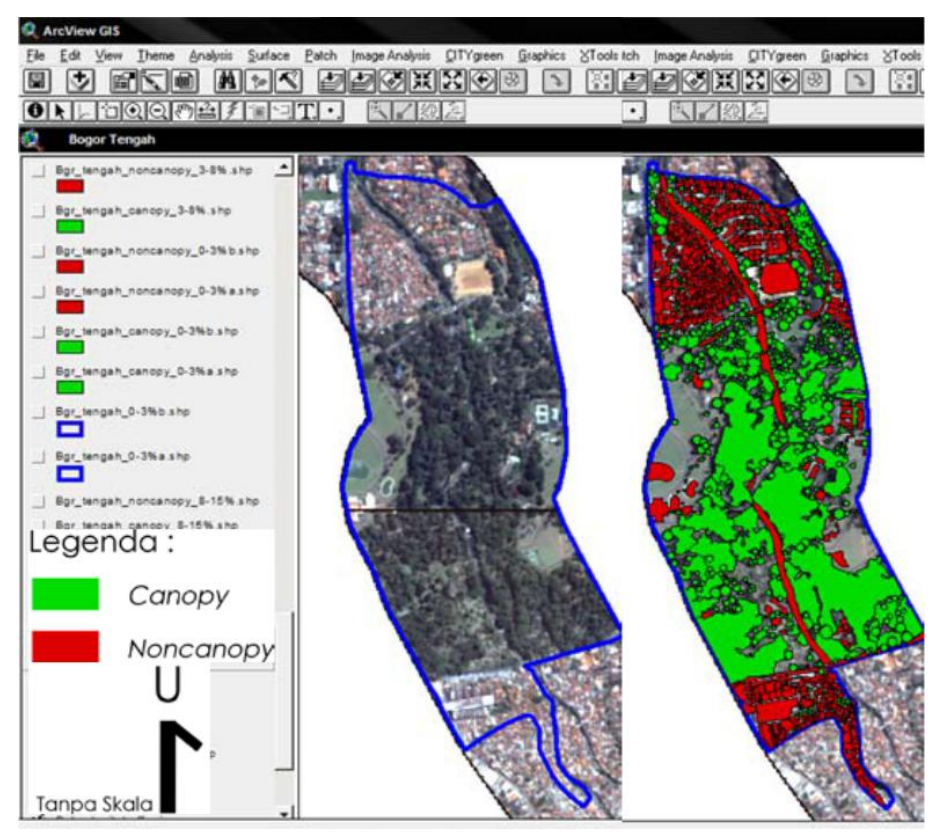

Gambar 5. Kondisi real area Kecamatan Bogor Tengah kemiringan lereng 3-8\% (kiri) dan digitasinya (kanan)

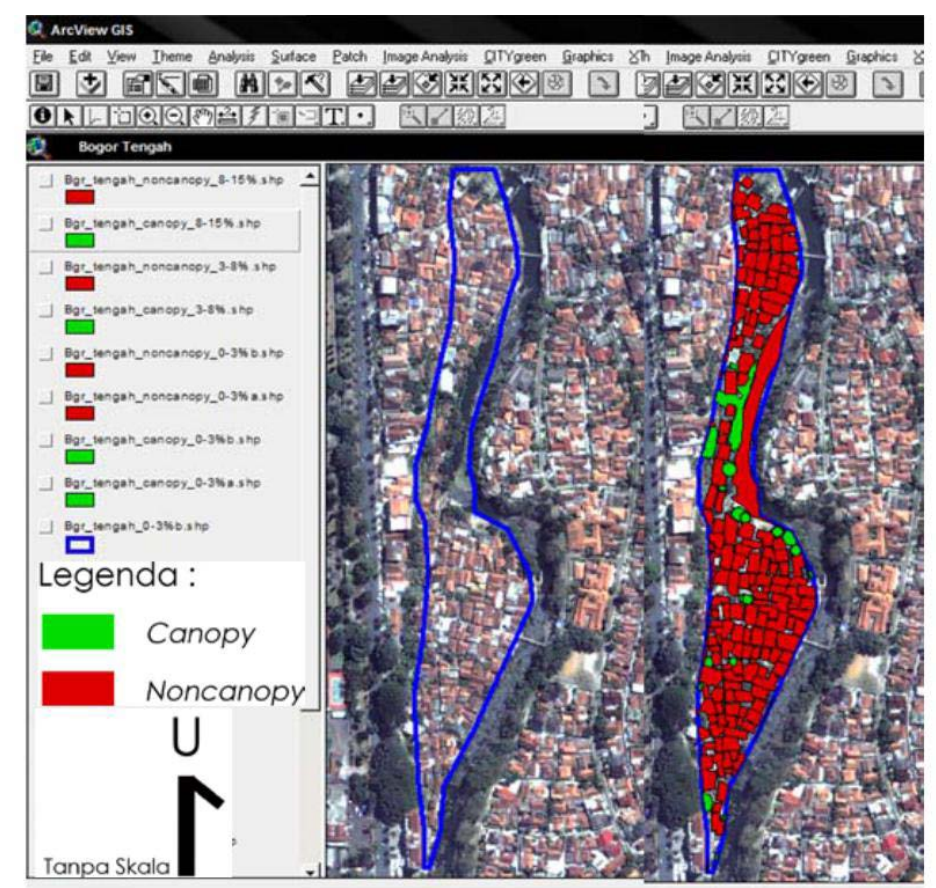

Gambar 6. Kondisi real area Kecamatan Bogor Tengah kemiringan lereng 8-15\% (kiri) dan digitasinya (kanan) 


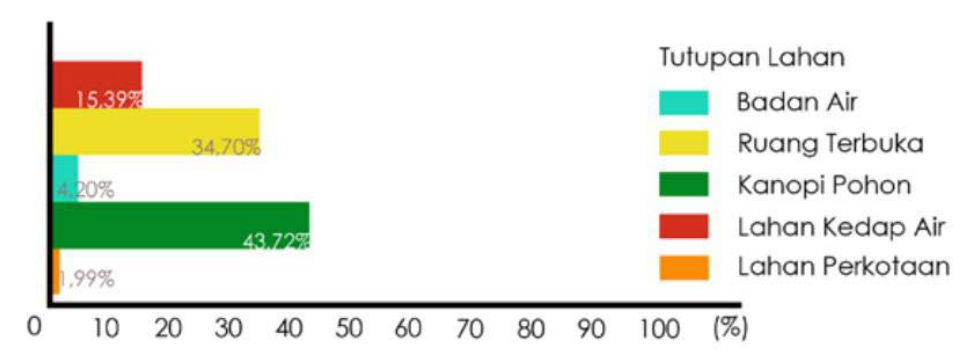

Gambar 7. Diagram perbandingan tutupan lahan pada area kemiringan lereng 3-8\% Kec. Bogor Tengah

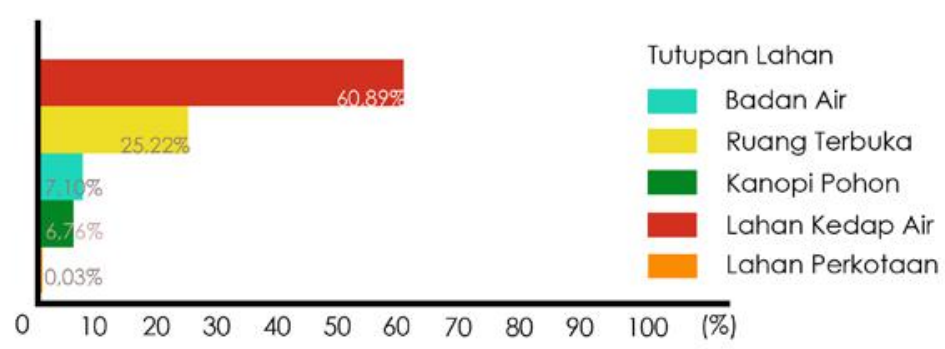

Gambar 8. Diagram perbandingan tutupan lahan pada area kemiringan lereng 8-15\% Kec. Bogor Tengah

Dapat disimpulkan bahwa kanopi pohon pada masing-masing area sanggup mereduksi 3,63\% - 13,89\% volume aliran permukaan setiap hektarnya (Gambar 9). Jika range persentase pada Gambar 9 dirata-rata, maka dapat diasumsikan bahwa kanopi pohon pada lokasi penelitian mampu mereduksi $\pm 7,55 \%$ dari total volume aliran permukaan. Hal ini menunjukkan bahwa kondisi pada area studi masih dibawah standar rata-rata sempadan sungai yang seharusnya dapat mereduksi $\pm 70-90 \%$ volume aliran permukaan (American Forest 2002).

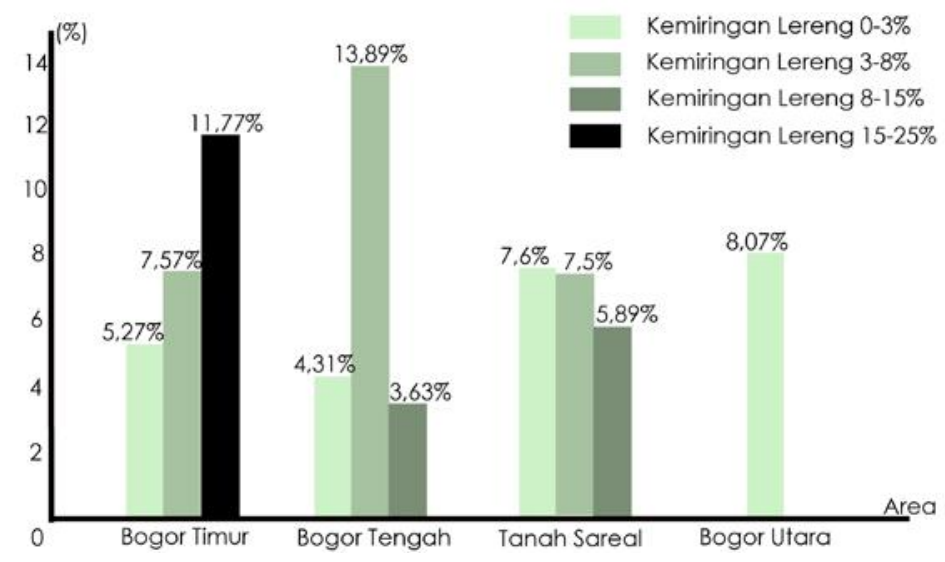

Gambar 9. Diagram persentase pengurangan volume aliran permukaan pada kondisi tanpa pohon dengan kondisi real 


\section{Simpulan}

Perbandingan area terbangun dengan RTH didapat bahwa yang memiliki nilai rasio terbesar adalah Kecamatan Tanah Sareal dengan persentase area terbangun sebesar $40,66 \%$ dan RTH sebesar $18,22 \%$ serta tutupan lain-lain sebesar $41,12 \%$ dari luas total (Gambar 2), atau secara sederhana rasio yang diperoleh adalah $2: 1$ (terbangun : RTH), sedangkan yang memiliki rasio terkecil adalah Kecamatan Bogor Tengah dengan persentase area terbangun sebesar 30,12\% dan RTH sebesar 30,42 \% serta tutupan lain sebesar 39,46\% dari luas total (Gambar 2), atau secara sederhana rasio yang diperoleh adalah $1: 1$ (terbangun : RTH). Berdasarkan Kepres No. 32/1990 dan PP No. 47/1997, kondisi sempadan pada Kecamatan Bogor Tengah dikatakan ideal dengan proporsi terbangun, RTH, dan lain-lain seimbang, sedangkan tiga Kecamatan lain dikategorikan kurang ideal. Hasil pendugaan manfaat kanopi pohon dalam mereduksi aliran permukaan ditinjau dari pengurangan volume aliran permukaan pada kondisi tanpa pohon dengan kondisi real (Gambar 9) dapat diasumsikan bahwa kanopi pohon di sempadan Sungai Ciliwung Tengah, Kota Bogor sejauh $300 \mathrm{~m}$ sebelah kiri dan kanan sungai mampu mereduksi $\pm 7,55 \%$ dari total volume aliran permukaan yang didapat dari analsis CITYgreen 5.4. Hal ini menunjukkan bahwa kondisi pada area studi masih dibawah standar rata-rata sempadan sungai yang seharusnya dapat mereduksi $\pm 70-90 \%$ volume aliran permukaan (American Forest 2002).

Hasil dari penelitian dengan menggunakan software CITYgreen 5.4 ini diharapkan dapat menjadi gambaran dan bahan rekomendasi bagi pemerintah Kota Bogor, terlebih kepada pemerintah di setiap kecamatan, bahwa keberadaan ruang terbuka hijau penting bagi kelangsungan dan keberlanjutan lingkungan kota, termasuk daerah sekitar Sungai Ciliwung.

\section{Daftar Pustaka}

American Forest. 2002. CITYgreen 5.0: User Manual. American Forest, Washington DC.

Anonim. 2010. Profil Kota Bogor. Tersedia online dalam: http://www.kotabogor.go.id (diakses pada 20 Februari 2010).

Anonim. 2010. Profil Kota Bogor. Tersedia online dalam: http://www.wikipedia.org (diakses pada 20 Februari 2010).

[Bappeda]. 2007. Master Plan Drainase Kota Bogor. Badan Perencanaan Pembangunan Daerah Kota Bogor, Bogor.

Budiman, A. 2010. Analisis Manfaat Ruang Terbuka Hijau untuk Meningkatkan Ekosistem Kota Bogor dengan Menggunakan Metode GIS. Skripsi Sarjana (tidak dipublikasikan). Institut Pertanian Bogor.

Siti Nurisjah dan Q. Pramukanto, 1995. Penuntun Praktikum Perencanaan Lanskap. Fakultas Pertanian. Institut Pertanian Bogor.

Technical Release 55. 1986. Urban Hydrology for Small Watersheds. Washington DC: USDA Soil Conservation Service. 